\title{
A high resolution study of the platelet ice ecosystem in McMurdo Sound, Antarctica: photosynthetic and bio-optical characteristics of a dense microalgal bloom
}

\author{
Kevin R. Arrigo ${ }^{1, *}$, Dale H. Robinson ${ }^{1, * *}$, Cornelius W. Sullivan ${ }^{2}$ \\ ${ }^{1}$ Department of Biological Sciences, University of Southern California, Los Angeles, California 90089-0371, USA \\ ${ }^{2}$ Graduate Program in Ocean Sciences, Hancock Institute for Marine Studies, University of Southern California,
} Los Angeles, California 90089-0373, USA

\begin{abstract}
Microalgal absorption, biomass, and photophysiology were monitored in conjunction with the vertical attenuation of photosynthetically active radiation and spectral irradiance within the lower congelation ice and the platelet ice layer in McMurdo Sound, Antarctica in 1989. Between 89 and $99 \%$ of the algal biomass was located within the $0.68 \mathrm{~m}$ thick platelet layer where standing crop, measured as chlorophyll a (chl a), increased from 280 to $1090 \mathrm{mg} \mathrm{m}^{-2}$ between October 26 and December 3. Algal biomass was highly stratified within the platelet ice layer. An increasing fraction, 38 to $90 \%$, of integrated chl $a$ was collected from the upper $0.125 \mathrm{~m}$ of the platelet layer, near the base of the congelation ice. Algal pigments accounted for $>95 \%$ of total light attenuation (ice + particles) within this layer. Sea ice microalgae exhibited photosynthetic properties consistent with extreme shade adaptation, including low mean pigment-specific absorption, $\bar{a} \cdot$, [0.0074 to $0.0040 \mathrm{~m}^{2}$ (mg chl a $\left.)^{-1}\right]$ and low assimilation numbers $\left[0.032\right.$ to $\left.0.180 \mathrm{mg} \mathrm{C}(\mathrm{mg} \mathrm{chl} \mathrm{a})^{-1} \mathrm{~h}^{-1}\right]$, both of which declined with depth. Vertical profiles revealed that low quantum yields for platelet ice assemblages were not a function of low temperature, as had previously been suspected, but vary with depth (and hence light level) from $0.033-0.051 \mathrm{~mol} \mathrm{C}$ (Ein absorbed $)^{-1}$ just beneath the base of the congelation ice to $0.086-0.113 \mathrm{~mol} \mathrm{C}$ (Ein absorbed) ${ }^{-1}$ (approaching the theoretical maximum) at a depth of $0.31 \mathrm{~m}$. Microalgae at the platelet ice surface exhibited photosynthetic characteristics which suggested that they were well adapted to the ambient light field while algae at depth appeared to retain excess photosynthetic capacity. The low $\bar{a}^{*}$ and compensation intensity exhibited by sea ice microalgae allowed accumulation of viable chl $a$ in excess of the theoretical maximum of $0.4 \mathrm{~g} \mathrm{~m}^{-2}$ (proposed for planktonic diatoms) to be supported by the available irradiance beneath sea ice. Fine-scale vertical profiles of photosynthetic parameters implied that values derived from course sampling of dense, stratified microalgal populations do not reliably reflect rates in situ.
\end{abstract}

\section{INTRODUCTION}

Numerous studies have demonstrated that photosynthetic and bio-optical characteristics of phytoplank-

\section{Present addresses}

- National Aeronautics and Space Administration, Goddard Space Flight Center, Code 971, Greenbelt, Maryland 20771, USA

- Alfred-Wegener-Institut für Polar- und Meeresforschung. Columbusstrasse, D-27568 Bremerhaven, Germany ton can vary with time and depth in the water column. Morel (1978) and Atlas \& Bannister (1980) both reported a reduction with depth in the mean specific absorption coefficient $\left(\bar{a}^{*}\right)$ for algae growing in green waters. Smith et al. (1989) reported vertical and temporal changes in the photosynthetic parameters $P_{\mathrm{m}}^{\mathrm{b}}$ (light saturated photosynthetic rate or assimilation number) and $I_{k}$ (photoadaptation parameter) in temperate coastal waters while Harrison \& Platt (1986) reported similar results from polar regions. It is now reasonably well understood that phytoplankton can 


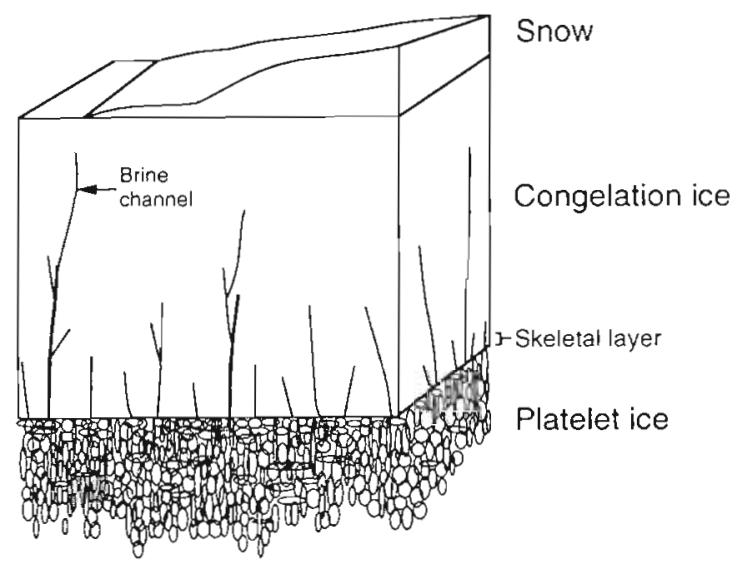

Fig. 1. Structure of sea ice typically found in McMurdo Sound, Antarctica

adapt to light intensity by altering the size (Perry et al. 1981) or number (Falkowski \& Owens 1980) of photosynthetic units, apparently to optimize the rate of light absorption (Henley \& Ramus 1989). However, there has been no systematic study of how photosynthetic efficiency $\left(\alpha^{b}\right), P_{\mathrm{m}}^{\mathrm{b}}, \bar{\alpha} \cdot$, and quantum yield of photosynthesis $(\phi)$ vary both temporally and with depth in sea ice. SooHoo et al. (1987) provided the most comprehensive treatment of the subject, reporting the photosynthetic characteristics of microalgae collected from congelation ice and from the relatively unconsolidated platelet ice layer below (Fig. 1). Although this relatively low resolution approach (only 1 sample from each community on a few days) provided valuable baseline information about the photosynthetic characteristics of ice algae, it precluded the assessment of vertical or temporal variability.

Sea ice, particularly platelet ice, is an excellent system in which to study the photosynthetic characteris- tics of microalgae under light-limited conditions (e.g. SooHoo et al. 1987. Arrigo et al. 1993). Sea ice in both the Arctic and Antarctic regions is known to harbor diverse microbial communities dominated by microalgae (primarily diatom species) which can attain chlorophyll a (chl a) standing crops in excess of

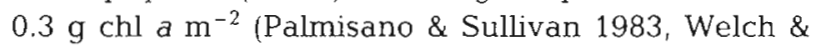
Bergman 1989). This algal biomass has a marked effect on light distribution within sea ice (Palmisano et al. 1987, Arrigo et al. 1991), providing an opportunity to study the effects of self-shading. Furthermore, the sea ice matrix provides a stable substrate on which microalgae are isolated from the effects of vertical mixing within the water column. In the present study we investigated how the interaction between irradiance transmission and biomass accumulation within sea ice affects the vertical distribution of chl $a$, rates of photosynthesis, and the bio-optical characteristics of algal cells. Concentrating on the dynamics of a dense diatom bloom which developed within the lower congelation ice and the platelet ice layer of McMurdo Sound, Antarctica in 1989, we obtained vertical profiles of the bio-optical characteristics and the physiological state of the algal community, including the skeletal layer of the congelation ice and at discrete depths within the platelet ice layer.

\section{METHODS}

Sample site. Sea ice biota was sampled in 2-yr-old fast-ice in McMurdo Sound approximately $3 \mathrm{~km}$ north of McMurdo Station ( $77^{\circ} 49.48^{\prime} \mathrm{S}, 166^{\circ} 41.45^{\prime} \mathrm{E}$ ). The congelation ice ranged in thickness from 2.5 to $2.7 \mathrm{~m}$, roughly 0.1 to $1.0 \mathrm{~m}$ thicker than was observed in this region in the 9 previous years (Table 1). Although local snow cover ranged from 0 to $0.10 \mathrm{~m}$, sampling was largely restricted to snow-free areas. Samples were

Table 1. Physical conditions and associated algal standing crops observed in McMurdo Sound, Antarctica, between 1980 and 1989

\begin{tabular}{|llccccc|}
\hline Date & Location & $\begin{array}{c}\text { Ice } \\
\text { depth } \\
(\mathrm{m})\end{array}$ & $\begin{array}{c}\text { Snow } \\
\text { depth } \\
(\mathrm{m})\end{array}$ & $\begin{array}{c}\text { Platelet } \\
\text { depth } \\
(\mathrm{m})\end{array}$ & Chlorophyll a & Source \\
\hline Nov-Dec 1980 & Cape Armitage & 2.2 & $0-20.0$ & $\mathrm{nr}$ & $131 \mathrm{mg} \mathrm{m}^{-2}$ & Palmisano \& Sullivan (1983) \\
Oct-Dec 1981 & Cape Armitage & $1.5-1.6$ & $1.5-7.2$ & $<0.1$ & $5-111 \mathrm{mg} \mathrm{m}^{-3}$ & Palmisano et al. (1985a) \\
Oct-Dec 1982 & Cape Armitage & $2.0-2.3$ & 5.0 & 0.8 & $\mathrm{nr}$ & Palmisano \& Sullivan (1985) \\
Oct-Dec 1982 & Cape Armitage & $\mathrm{nr}$ & $\mathrm{nr}$ & $\mathrm{nr}$ & $0.1-100 \mathrm{mg} \mathrm{m}^{-3}$ & Grossi et al. (1987) \\
Nov-Dec 1983 & Cape Armitage & 2.3 & 0 & 2.0 & $53-250 \mathrm{mg} \mathrm{m}^{-2}$ & Palmisano et al. (1985b) \\
Dec 1984 & E McMurdo Sound & $1.5-1.8$ & $3.0-10.0$ & $\mathrm{nr}$ & $\mathrm{nr}$ & Palmisano et al. (1986) \\
Nov-Dec 1985 & Cape Armitage & $2.4-2.5$ & $\mathrm{nr}$ & $\mathrm{nr}$ & $5-150 \mathrm{mg} \mathrm{m}^{-2}$ & Palmisano et al. (1988) \\
Dec 1986 & Erebus Ice Tongue & 2.0 & $\mathrm{nr}$ & $\mathrm{nr}$ & $\mathrm{nr}$ & Priscu et al. (1989) \\
Oct-Dec 1988 & Hut Point & $2.3-2.4$ & $0-5$ & 1.0 & $33-646 \mathrm{mg} \mathrm{m}^{-2}$ & This study \\
Oct-Dec 1989 & Hut Point & $2.5-2.7$ & 0 & 0.68 & $280-1090 \mathrm{mg} \mathrm{m}^{-2}$ & This study \\
nr: not reported & & & & & & \\
& & & & & &
\end{tabular}


collected within a $200 \mathrm{~m}^{2}$ quadrat at 1 to $5 \mathrm{~d}$ intervals between October 26 and December 24, 1989.

Irradiance measurements. Simultaneous measurements of photosynthetically active radiation (PAR) were made $1.0 \mathrm{~m}$ above the sea ice surface using a MER 1000 spectroradiometer and below the ice sheet with a MER 1010 spectroradiometer (Biospherical Instruments, San Diego, CA, USA). Each had been calibrated for wet and dry measurements using an identical light source at the factory and compared side by side in the field. A profile of downwelling PAR and spectral irradiance within the platelet layer on November 21, 1989, was obtained by raising the MER 1010 spectroradiometer through the loosely consolidated platelet ice layer. Caution precluded us from obtaining a complete profile due to fear of damaging the radiometer by impacting with the congelation ice sheet. For this reason, irradiance was not measured in the upper $0.10 \mathrm{~m}$ of the platelet ice.

Sample collection. Sea ice microalgae and the associated microbial community were collected from the bottom of the congelation ice using a SIPRE auger. All work done subsequent to bringing the core to the surface was carried out under an opaque tarpaulin to ensure that algae were not exposed to high surface irradiance. Core sections removed from the auger were immediately placed into dark, 2 I polyethylene bottles, to which $500 \mathrm{ml}$ of $0.2 \mu \mathrm{m}$ filtered seawater was added, and kept on ice until pracessing could take place. Ice platelets and the associated biota were collected from the core holes using a Nalgene ${ }^{\emptyset}$ beaker fitted with a $0.5 \mathrm{~m}$ long handle, and were then placed into dark, 2 l polyethylene sample bottles with seawater from the core hole.

The cores and ice platelets melted at $-1{ }^{\circ} \mathrm{C}$ for $12 \mathrm{~h}$. The salinity of the meltwater was monitored periodically and adjusted by the addition of $0.2 \mu \mathrm{m}$ filtered seawater to minimize salinity changes. All further treatments prior to light incubations took place at $-1{ }^{\circ} \mathrm{C}$ in very low light $\left(<5 \mu\right.$ Ein $\left.\mathrm{m}^{-2} \mathrm{~s}^{-1}\right)$.

Profiles. High resolution ( $0.125 \mathrm{~m}$ intervals) profiles of the interstitial seawater within the platelet layer and the upper $0.6 \mathrm{~m}$ of the underlying water column were obtained using the ADONIS sampling device (described in Dieckmann et al. 1992). Although effective for obtaining accurate profiles of most seawater constituents, chl a concentrations obtained using ADONIS are underestimates of levels contained within the platelet layer because only interstitial water was sampled and a fraction of sea ice microalgae adhere to the ice crystal surfaces (Sullivan unpubl.). However, assuming a consistent fraction of the total algal population was collected at each depth, this device provides valuable information about microalgal distributions within the platelet layer. As an independent test of this assumption, chl a distributions predicted from profiles of light attenuation within the platelet ice were similar to distributions collected with ADONIS (Arrigo unpubl.).

Total biomass estimation. Chl a and phaeopigment concentrations were assayed using the method of Parsons et al. (1984). The concentration of chl a (C, mg $\mathrm{m}^{-3}$ ) within a given congelation ice core was converted to areal standing $\operatorname{crop}\left(C_{\mathrm{c}}, \mathrm{mg} \mathrm{m}^{-2}\right)$ using the equation

$$
C_{c}=C-\frac{V}{0.00456} D
$$

where $V$ is the volume of the collected core $\left(\mathrm{m}^{3}\right)$; 0.00456 is the cross sectional area of the core $\left(\mathrm{m}^{2}\right)$; and $D$ is a factor to correct for dilution by filtered seawater additions.

The standing crop of chl a within the platelet layer $\left(C_{p}, \mathrm{mg} \mathrm{m}^{-2}\right)$ was estimated by collecting all the platelet ice and associated algal biomass that floated up into the core holes as a result of platelet ice buoyancy. Divers verified visually and by photography that only biomass located directly beneath the core hole was collected using this method (R. Moe pers. comm.). $C$ collected in this manner was converted to $C_{p}$ using the equation

$$
C_{p}=C \frac{V}{0.00811} D
$$

where 0.00811 is the cross sectional area of the core hole $\left(\mathrm{m}^{2}\right)$.

Although profiles of chl a obtained with ADONIS are underestimates of concentrations in situ, it is possible to couple information concerning integrated chl $a$ and its distribution within the platelet ice to calculate the chl a concentration $\left(C_{a}, \mathrm{mg} \mathrm{m}^{-3}\right)$ within a given layer. $C_{\mathrm{a}}$ can be calculated by the equation

$$
C_{\mathrm{a}}=\frac{C_{\mathrm{p}} f}{z}
$$

where $C_{\mathrm{p}}\left(\mathrm{mg} \mathrm{m} \mathrm{m}^{-2}\right)$ is the integrated chl a biomass within the platelet layer obtained from Eq. (2); $f$ is the fraction of total biomass in that layer determined from ADONIS chl a profiles; and $z$ is the layer thickness $(0.125 \mathrm{~m})$ as dictated by the profiling interval.

Photosynthesis vs irradiance (PI) incubations. PI incubations of microalgae collected from interstitial water of the platelet layer were carried out using a modification (Arrigo \& Sullivan 1992) of the method of Lewis \& Smith (1983) whereby a small volume incubation chamber (photosynthetron) allowed simultaneous incubations at 24 irradiance levels ranging from 0.5 to $250 \mu$ Ein $\mathrm{m}^{-2} \mathrm{~s}^{-1}$ (measured using a QSL $1004 \pi$ PAR collector, Biospherical Instruments, Inc., San Diego). Light was provided by a $500 \mathrm{~W}$ tungsten-halogen lamp and levels were adjusted using acetate neutral density filters. 


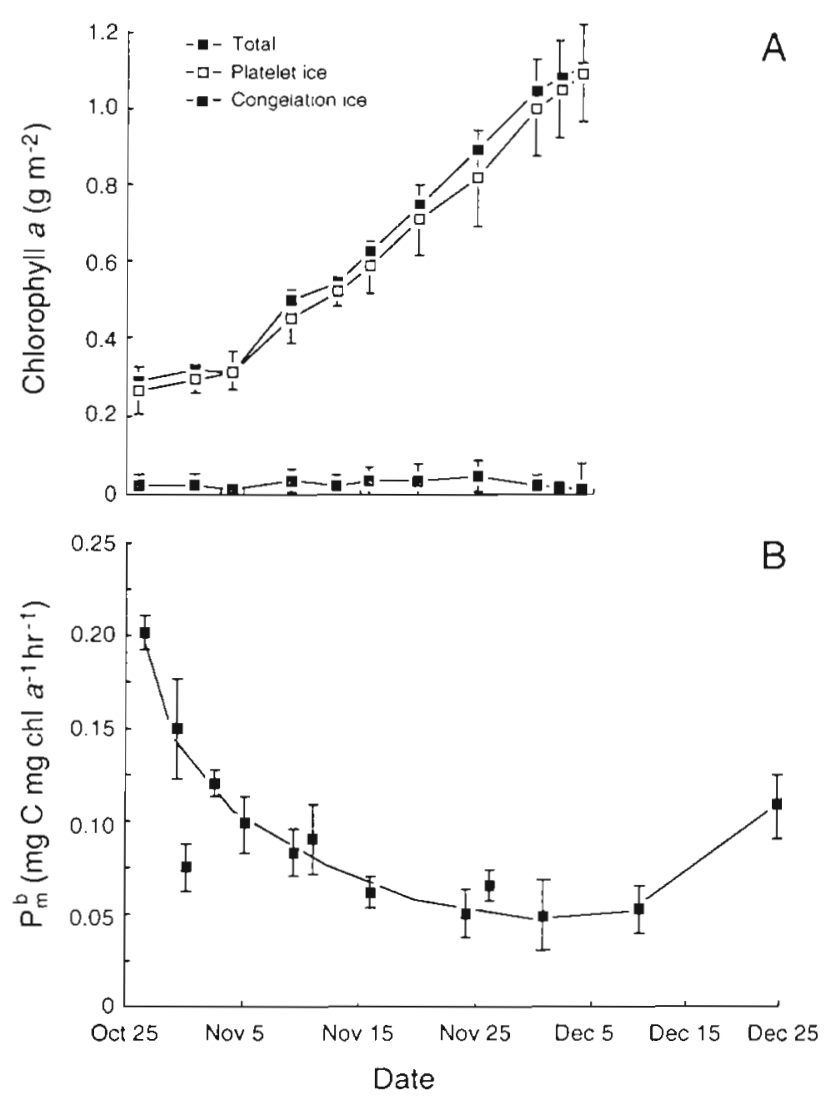

Fig. 2. Seasonal changes in (A) vertically integrated chlorophyll a observed in the congelation and platelet ice layers of McMurdo Sound, Antarctica, in 1989; and (B) maximum biomass specific photosynthetic rate, $P_{\mathrm{m}}^{\mathrm{b}}$, for the platelet ice algal assemblage

The PI parameters, $P_{\mathrm{m}}^{\mathrm{b}}$ [light saturated photosynthetic rate, $\operatorname{mg} \mathrm{C}(\mathrm{mg} \text { chl } a)^{-1} \mathrm{~h}^{-1}$ ] and $\alpha^{b}$ [photosynthetic efficiency, $\operatorname{mg} C(m g \mathrm{chl} a)^{-1} \mathrm{~h}^{-1}\left(\mu\right.$ Ein $\mathrm{m}^{-2}$ $\left.s^{-1}\right)^{-1}$ ] were derived using the equations of Platt et al. (1980) and the curve-fitting procedure of Zimmerman et al. (1987). The spectral-dependent parameter $\alpha^{b}$ was spectrally corrected to approximate photosynthetic efficiency in situ rather than in the white light incubator according to the relationship

$$
\alpha^{b}=\alpha_{\text {incubator }}^{b} \frac{\bar{a}^{*}{ }_{\text {in situ }}}{\bar{a}^{*} \text { incubator }}
$$

where $\alpha^{b}$ is the corrected photosynthetic efficiency and $\alpha^{b}$ incubator is the photosynthetic efficiency obtained using the photosynthetron. $\bar{a} \cdot{ }_{\text {in situ }}$ and $\bar{a}^{*}$ incubator were calculated from Eq. (5) using irradiance spectra characteristic of the under-ice environment and the tungsten-halogen lamp, respectively.

Specific absorption coefficient. The specific absorption coefficient for microalgae was determined using the method of Mitchell \& Kiefer (1988) and $\beta$-corrected using the equation of Bricaud \& Stramski (1990). Because specific absorption spectra exhibit marked spectral variation within the visible range $(400$ to $700 \mathrm{~nm})$ specific absorption has been spectrally averaged over this interval to obtain the mean specific absorption coefficient in situ, $\bar{a}^{*}$. This was accomplished by weighting each wavelength according the spectral distribution of the in situ irradiance (Bannister 1974) such that

$$
\bar{a}^{*}=\frac{\int_{700}^{400} a^{*}(\lambda) E(\lambda) \mathrm{d} \lambda}{\int_{700}^{400} E(\lambda) \mathrm{d} \lambda}
$$

where $E(\lambda)$ is the ambient under-ice irradiance spectrum. The value of $\bar{a}^{*}$ in Eq. (5) is a function of the distribution of spectral irradiance, not its magnitude. As the distribution of $E(\lambda)$ approaches $a^{*}(\lambda), \bar{\alpha}^{*}$ increases, regardless of the magnitude of PAR.

The quantum yield of photosynthesis, $\phi[\mathrm{mol} \mathrm{C}$ (Ein absorbed $)^{-1}$, was calculated according to Tilzer et al. (1985) as

$$
\phi=\frac{\alpha^{\mathrm{b}}}{43.2 \overline{\mathrm{a}}^{*}}
$$

where 43.2 is a units conversion factor.

\section{RESULTS}

\section{Microalgal standing crop}

The standing crop of chl $a$ in the sea ice of McMurdo Sound in 1989 increased steadily from $280 \mathrm{mg} \mathrm{m}^{-2}$ on October 26 to $1090 \mathrm{mg} \mathrm{m}^{-2}$ on December 3 (Fig. 2A). During our study, 89 to $99 \%$ of the algal biomass in the ice column was located within the platelet layer, with most of the remainder contained within the 0.01 to $0.02 \mathrm{~m}$ thick skeletal layer at the lower margin of the congelation ice (Fig. 1). The algal community was

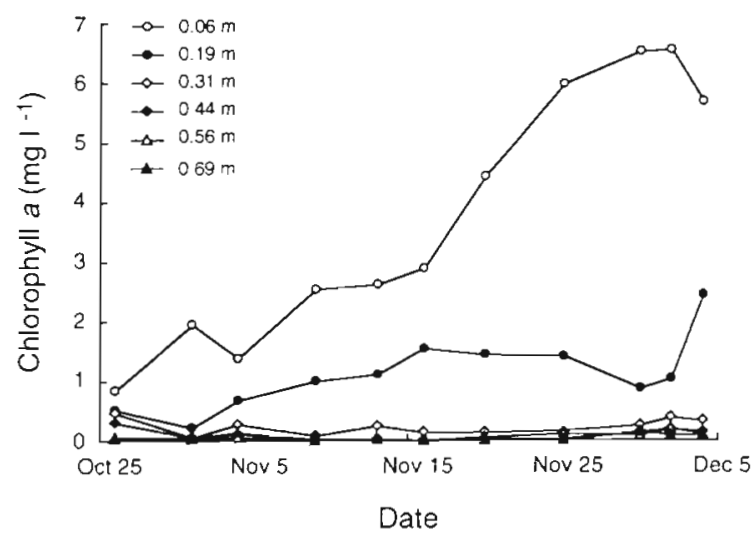

Fig. 3. Vertical distributions of chlorophyll a within the platelet ice layer between October 26 and December 3, 1989, in McMurdo Sound, Antarctica, as estimated using Eq. (3) 
dominated $(>95 \%$ ) by the colonial pennate diatom Nitzschia stellata (Manguin).

Distributions of algal pigments were highly stratified within the platelet ice layer (Fig. 3). The fraction of integrated chl a located in the upper $0.125 \mathrm{~m}$ (near the congelation ice-platelet ice interface) varied temporally from 38 to $90 \%$. Concentrations of chl $a$ in this layer increased from $0.85 \mathrm{mg} \mathrm{l}^{-1}$ on October 26 to $6.55 \mathrm{mg}$ $1^{-1}$ on December 3 (Fig. 3). An analysis of the available literature indicates that chl a concentrations in Antarctic and Arctic sea ice typically range from 0.1 to $0.9 \mathrm{mg} \mathrm{chl} a$ $\mathrm{l}^{-1}$ and 0.3 to $1.0 \mathrm{mg} \mathrm{chl} \mathrm{l}^{-1}$, respectively.

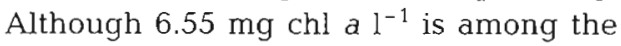
highest reported in situ chl a concentrations for sea ice that we know of, it is similar to the value of $5.32 \mathrm{mg} \mathrm{chl} \mathrm{a} \mathrm{l^{-1 }}$ reported by Hoshiai (1981) for a relatively thin $0.02 \mathrm{~m}$ thick bottom-ice microalgal community near Syowa Station $\left(69.5^{\circ} \mathrm{S}, 38^{\circ} \mathrm{E}\right)$, and $10.1 \mathrm{mg} \mathrm{chl} \mathrm{a} \mathrm{l}^{-1}$ observed by Lizotte \& Sullivan (1992) in the $0.01 \mathrm{~m}$ thick skeletal layer of McMurdo Sound.

\section{Platelef ice bio-optics}

A typical time series of downwelling surface irradiance in McMurdo Sound (collected in 1984) is shown in Fig. 4 to illustrate how light availability increases both in magnitude and photoperiod $(F)$ during the spring bloom. On September 17, $F$ was approximately $12 \mathrm{~h}$ with local noon irradiance reaching $500 \mu \mathrm{E} \mathrm{m} \mathrm{m}^{-2}$ $\mathrm{s}^{-1}$. $F$ continued to increase, reaching $24 \mathrm{~h}$ by midOctober. Although at this time irradiance at local midnight was still quite low, noon irradiance had increased to between 800 and $900 \mu \mathrm{E} \mathrm{m}^{-2} \mathrm{~s}^{-1}$. On November 12 under cloud-free skies, irradiance at midnight and noon approached 500 and $1300 \mu \mathrm{E} \mathrm{m}^{-2} \mathrm{~s}^{-1}$, respectively. Irradiance continued to increase through December 4 when midnight values were approximately $700 \mu \mathrm{E} \mathrm{m}^{-2} \mathrm{~s}^{-1}$ and noon values were nearly $1400 \mu \mathrm{E} \mathrm{m}^{-2} \mathrm{~s}^{-1}$.

The bulk diffuse attenuation coefficient, $K_{\mathrm{d}}$, decreased sharply with increasing depth in the platelet ice layer (as seen by the increase in the slope of $\ln (\mathrm{PAR}) / z$ in Fig. 5) in conjunction with the decrease in chl a concentration. By decomposing the bulk $K_{\mathrm{d}}$ into attenuation by ice crystals $\left(K_{\mathrm{di}}\right)$ and by particles $\left(K_{\mathrm{dp}}\right)$ :

$$
K_{\mathrm{d}}=K_{\mathrm{di}}+K_{\mathrm{dp}}
$$

(Arrigo et al. 1991) the relative contributions by these 2 components can be compared (assuming absorption by

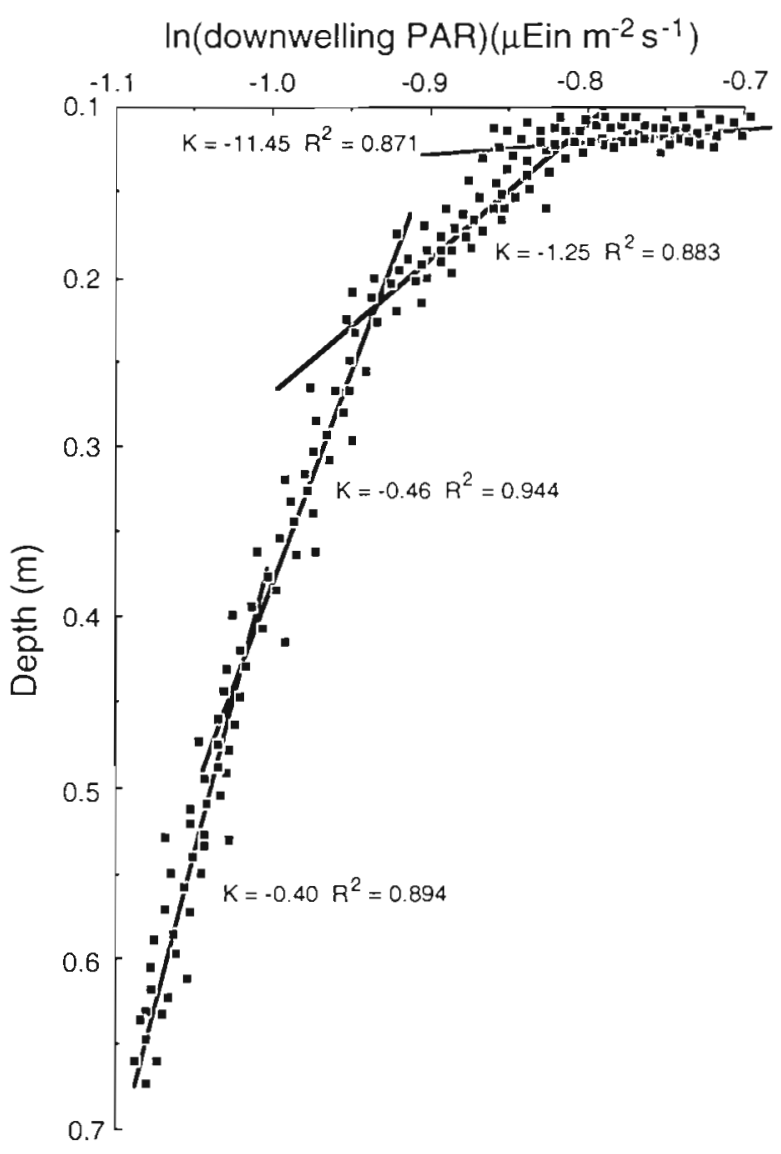

Fig. 5. Plot of ln (downwelling PAR) versus depth in the platelet ice. The slopes of the regression equations provide an estimate of the attenuation coefficient, $K$, at different depths within the platelet ice. Data collected from McMurdo Sound, Antarctica, on November 21, 1989 


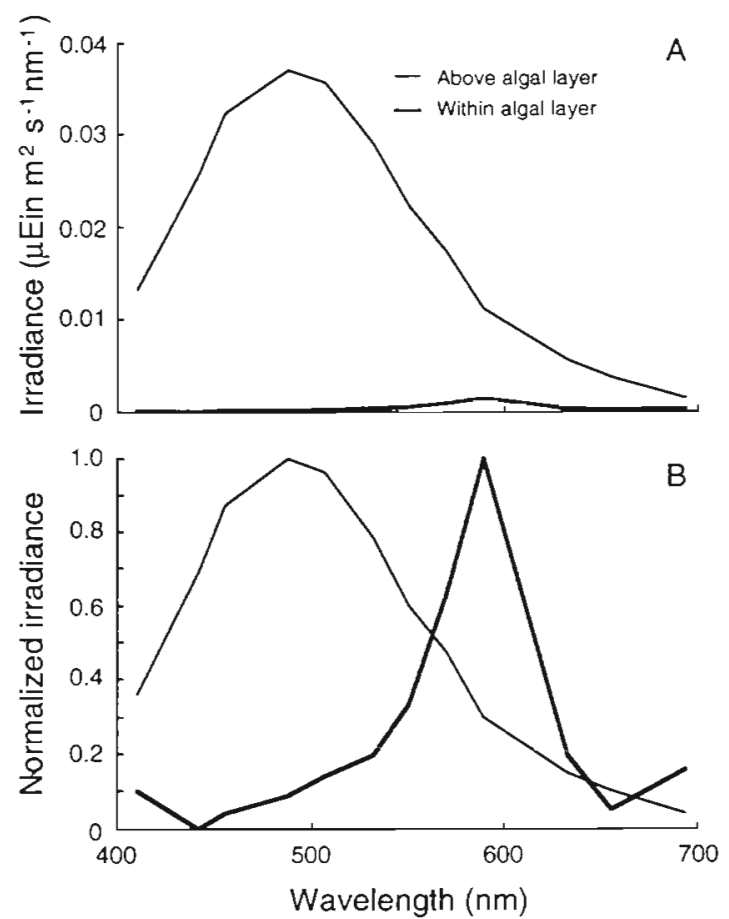

Fig. 6. Downwelling irradiance spectra measured above and within the platelet ice algal community in McMurdo Sound on November 21, 1989, expressed in (A) raw and (B) normalized form

DOM is insignificant). Arrigo et al. (1991) showed that $K_{\mathrm{d} \mathrm{t}}=0.43 \mathrm{~m}^{-1}$ for virtually particle-free platelet ice. At a depth of $0.10 \mathrm{~m}$ below the congelation ice/platelet ice interface $K_{d}=11.45 \mathrm{~m}^{-1}$ (Fig. 5) so from Eq. (7) it can be estimated that $K_{\mathrm{dp}}=11.02 \mathrm{~m}^{-1}$. Thus, absorption and scattering by the biological community accounted for $>96 \%$ of total light attenuation at this depth. Because concentrations of chl a were considerably higher within $0.10 \mathrm{~m}$ of the congelation ice/platelet ice interface (Fig. 3), where light measurements were not made, the percent contribution of biogenic particles to total light attenuation in this region probably approached $100 \%$. The depth-averaged attenuation by algal pigments $\left(K_{\mathrm{dp}}=6.4 \mathrm{~m}^{-1}\right)$ was $>16$-fold greater than attenuation by the platelet ice alone for the chl a concentrations observed on November 21 in McMurdo Sound.

In sea ice with low pigment concentrations, the spectral irradiance peak was $0.037 \mu \mathrm{E} \mathrm{m}^{-2} \mathrm{~s}^{-1} \mathrm{~nm}^{-1}$ and centered at 470 to $480 \mathrm{~nm}$ (Fig. 6). Transmission declined considerably toward the violet $\left(0.011 \mu \mathrm{E} \mathrm{m}^{-2}\right.$ $\left.\mathrm{s}^{-1} \mathrm{~nm}^{-1}\right)$ and red $\left(0.002 \mu \mathrm{E} \mathrm{m}^{-2} \mathrm{~s}^{-1} \mathrm{~nm}^{-1}\right)$ regions of the spectrum. This spectral irradiance distribution is consistent with previous observations made beneath relatively pigment-free sea ice in both Arctic (Maykut \& Grenfell 1975, Grenfell \& Maykut 1977) and Antarctic (SooHoo et al. 1987. Arrigo et al. 1991) regions, and is complimentary to the diffuse attenuation spectrum for Antarctic sea ice which exhibits minimum attenuation in the 470 to $480 \mathrm{~nm}$ range (Grenfell \& Maykut 1977). The presence of a dense microalgal community resulted in a marked shift in the spectral transmission peak from $475 \mathrm{~nm}$ to $600 \mathrm{~nm}$. This shift is seen more clearly when irradiance spectra are normalized to their maximum values (Fig. 6B).

\section{Photosynthetic characteristics}

PI curves obtained for sea ice algae showed little scatter, allowing accurate estimation of photosynthetic parameters (Fig. 7). $P_{\mathrm{m}}^{\mathrm{b}}$ obtained from bulk samples of platelet ice with the associated microalgal community changed markedly throughout the 1989 sampling season (Fig. 2B). Between October 26 and November 15, $P_{\mathrm{m}}^{\mathrm{b}}$ declined $75 \%$, from 0.20 to $0.05 \mathrm{mg} \mathrm{C}(\mathrm{mg} \mathrm{chl} \mathrm{a})^{-1}$ $\mathrm{h}^{-1} \cdot P_{\mathrm{m}}^{\mathrm{b}}$ then remained relatively constant until December 3 when it increased in conjunction with the ablation of most of the platelet ice layer, reaching $0.11 \mathrm{mg}$ $\mathrm{C}(\mathrm{mg} \mathrm{chl} a)^{-1} \mathrm{~h}^{-1}$ on December 24.

The magnitudes of $P_{m}^{b}, \alpha^{b}, \bar{a}^{*}$, and $\phi$ exhibited by microalgae growing in the skeletal layer were statistically indistinguishable from values for algae collected from the uppermost layer (the top $0.06 \mathrm{~m}$ ) of the platelet ice (Fig. 8) on all sampling dates. $P_{\mathrm{m}}^{\mathrm{b}}$ exhibited
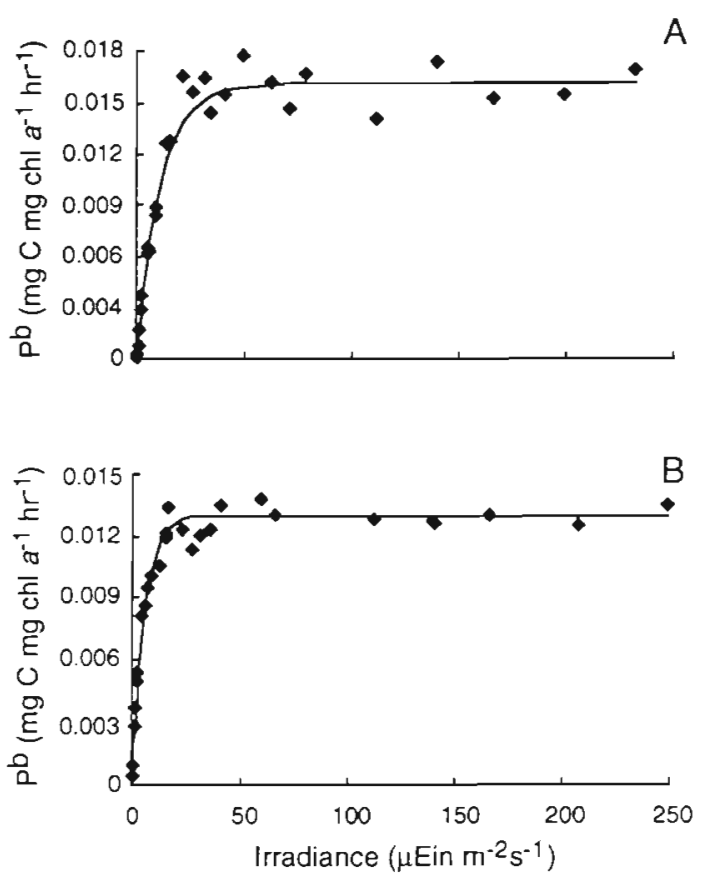

Fig. 7. Photosynthesis versus irradiance curves measured for algae collected on October 26 from the depths of (A) $0.06 \mathrm{~m}$ and (B) $0.31 \mathrm{~m}$. Curve was fitted to the model of Platt et al. (1980) 

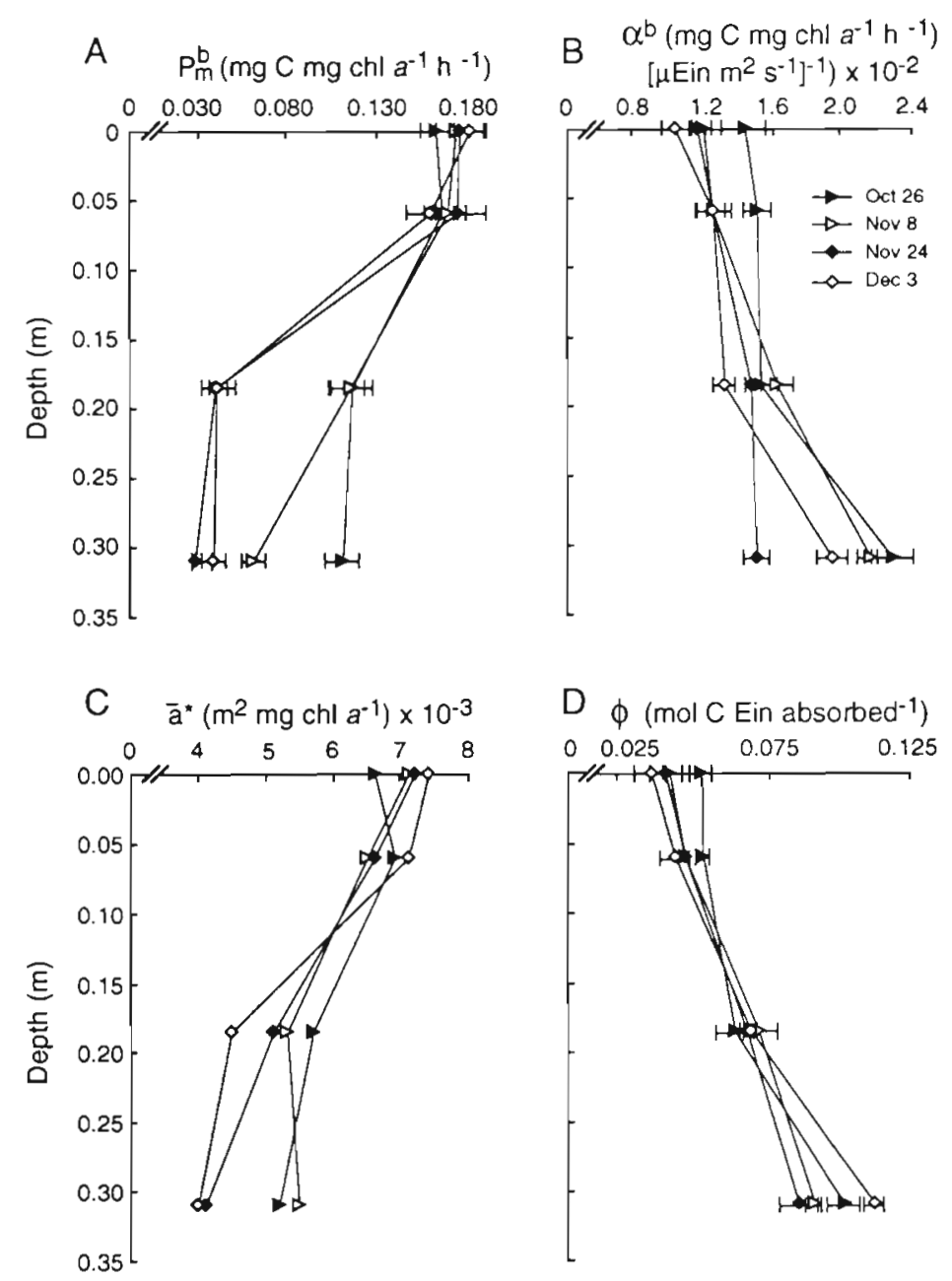

Fig. 8. Vertical profiles of (A) $P_{\mathrm{m}}^{b},(B) \alpha^{b},(C) \bar{a}^{*}$, and (D) $\phi$ obtained from cells collected from the interstitial water of the platelet ice of McMurdo Sound, Antarctica in 1989. Error bars represent the standard deviation of the parameter estimate

the least variability between the skeletal layer and the upper platelet ice, agreeing to within a seasonal average of $4 \%$ (Fig. 8A). The parameter showing the greatest variation between these 2 habitats was $\bar{a}^{*}$, but even it varied only by 4 to $8 \%$ (Fig. $8 \mathrm{C}$ ).

All 4 photosynthetic parameters exhibited marked vertical variation between the depths of $0.06 \mathrm{~m}$ and $0.31 \mathrm{~m}$ within the platelet layer (Fig. 8). Because of low biomass or low activity, carbon uptake for algae below a depth of $0.31 \mathrm{~m}$ was undetectable. $P_{\mathrm{m}}^{\mathrm{b}}$ and $\bar{a}^{*}$ displayed a consistent and marked decline with increasing depth (Fig. 8A \& 8C, respectively), presumably in response to irradiance diminished in magnitude (in the case of $P_{\mathrm{m}}^{\mathrm{b}}$ ) and spectral quality (in the case of $\bar{a}^{*}$ ). This response was most severe on December 3 when $P_{\mathrm{m}}^{\mathrm{b}}$ and $\bar{a}^{\cdot}$ declined by $74 \%$ and $44 \%$, respectively. In contrast, $\alpha^{\mathrm{b}}$ and $\phi$ increased with increasing depth in the platelet layer (Fig. 8B \& 8D, respectively). Again, the degree of stratification varied temporally, with responses most extreme on December 3 when $\alpha^{b}$ and $\phi$ increased $53 \%$ and $243 \%$, respectively. On that date, the peak value for $\phi$ measured during our study $\left(0.113\right.$ mol C Ein absorbed $\left.^{-1}\right)$ was observed at a depth of $0.31 \mathrm{~m}$. This value approximates the theoretical maximum of 0.100 to 0.125 mol $C$ (Ein absorbed $)^{-1}$

Microalgae at the top of the platelet layer exhibited higher chl a specific absorption and a greater blue:red peak height ratio than microalgae at depth (Fig. 9). Respective blue : red ratios for microalgae collected from these 2 regions were 1.62 and 1.24 , suggesting that microalgae at the lower margin of the algal layer were more highly packaged (Duysens 1956, Morel \& Bricaud 1981). In addition, a more pronounced absorption 'shoulder' at $500 \mathrm{~nm}$ was present for algae growing at the base of the algal layer (within the platelet ice interior), reflecting enhanced absorption by fucoxanthin.

\section{DISCUSSION}

\section{Biomass accumulation}

The peak standing crop of $1090 \mathrm{mg}$ chl a $\mathrm{m}^{-2}$ measured during our study is $>3$-fold higher than the previous maximum standing crop of $310 \mathrm{~g} \mathrm{chl} \mathrm{a} \mathrm{m}^{-2}$ (Palmisano \& Sullivan 1983) reported for McMurdo Sound. Accumulation of chl $a$ within the platelet layer in 1989 was also 2 to 3 orders of magnitude higher than the $5 \mathrm{mg} \mathrm{m}^{-2}$ typically observed

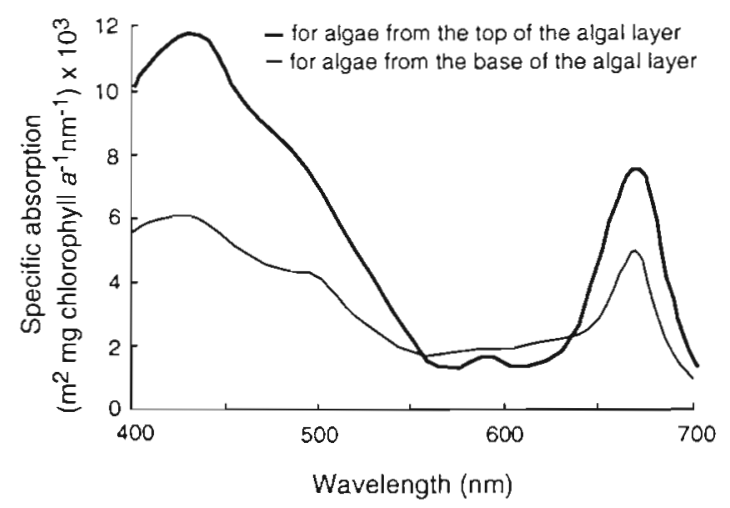

Fig. 9. Chlorophyll a specific absorption spectra of microalgae cells collected from the top and base of the algal layer in the platelet ice of McMurdo Sound, Antarctica 
in Antarctic pack ice (Dieckmann et al. 1990). The establishment and maintenance of high accumulations of algal biomass in platelet ice is likely due to the combined effects of (1) a large surface area for algal attachment, (2) relatively high rates of nutrient flux, and (3) low microalgal loss rates.

Platelet ice provides a much larger surface area for algal attachment and growth than the skeletal layer where most of the biomass within the congelation ice is concentrated. For example, a $0.02 \mathrm{~m}$ thick skeletal layer with ice crystals spaced $0.6 \mathrm{~mm}$ apart provides approximately $67 \mathrm{~m}^{2}$ of surface area per $\mathrm{m}^{2}$ of horizontal surface, with relatively little interstitial space for seawater exchange. In contrast, a layer of platelet ice consists of $80 \%$ seawater by volume (Bunt \& Lee 1970) with roughly circular ice platelets approximately $0.1 \mathrm{~m}$ in diameter and $10 \mathrm{~mm}$ thick. With these characteristics, a platelet layer 0.6 to $0.7 \mathrm{~m}$ thick as observed in 1989 would have a surface area of approximately $400 \mathrm{~m}^{2}$ per $\mathrm{m}^{2}$ of horizontal surface, with a large amount of interstitial space. Therefore it would be capable of supporting a more robust algal bloom. In support of this view, Grossi et al. (1987), working near the location of our study area during the 1982 austral summer, also reported peak chl a standing crops in the platelet ice layer which were approximately 10 -fold greater than those observed in congelation ice (8.5 and $76 \mathrm{mg}$ chl a $\mathrm{m}^{-2}$, respectively).

The platelet ice is also a habitat characterized by relatively rapid nutrient exchange. In contrast to the congelation ice where physical nutrient replenishment is controlled by thermodynamic processes within the ice sheet when a layer of platelet ice is present (i.e. convection and brine drainage), the rate of nutrient exchange within platelet ice has been observed to covary with tidal height and therefore may be influenced by sub-ice currents (Arrigo \& Sullivan unpubl.). In 1989, the interstitial seawater within the platelet ice layer was estimated to turn over every 1.6 to $12.0 \mathrm{~d}$ depending on tidal cycle (Arrigo \& Sullivan unpubl.). Thus, unlike the congelation ice, nutrients can be exchanged within platelet ice whether or not the congelation ice sheet is actively growing. ADONIS profiles demonstrated that nutrient exchange mechanisms within the platelet layer operated efficiently and that despite high algal biomass, platelet ice macronutrients remained high (Dieckmann et al. 1992, Arrigo unpubl.). However, an unusually thick platelet ice layer may restrict nutrient exchange and reduce biomass accumulation. For instance, in 1983, snow and congelation ice thickness in McMurdo Sound were similar to those observed in 1989 (Palmisano et al. 1985b) yet the peak algal standing crop was much lower (Table 1) The most obvious difference between the 2 years was the thickness of the platelet layer. Whereas the $0.68 \mathrm{~m}$ platelet layer present in 1989 was sufficiently thin to allow ample nutrient replenishment, the $2.0 \mathrm{~m}$ layer observed in 1983 may have overly restricted nutrient flux to the algal community, reducing algal growth rates. This hypothesis is consistent with findings of Palmisano et al. (1985b) which indicate that the platelet ice community present in 1983 may have been nutrient limited. We speculate that a platelet layer too thin may not provide the needed space for a large accumulation of algal biomass and a layer which is too thick may overly restrict the supply of nutrients from the water column below. Platelet ice of intermediate thickness $(-0.5 \mathrm{~m})$, similar to that observed in 1989 , may provide a nearly optimal environment for microalgal growth with its relatively large surface area and high rates of seawater exchange.

Numerous studies point out that platelet ice acts as a barrier to both metazoan grazing and algal sinking (Bunt \& Wood 1963, Meguro et al. 1967, Bunt \& Lee 1970), substantially reducing microalgal losses due to these processes. In addition, Vincent \& HowardWilliams (1989) have observed that the accumulation of large amounts of chl $a$ in microbial mats growing in Antarctic streams were the result of depressed rates of bacterial decomposition at low temperatures. They observed nearly complete decomposition of microbial mats incubated at high $\left(25^{\circ} \mathrm{C}\right)$ temperatures whereas those incubated at ambient in situ temperatures $\left(5^{\circ} \mathrm{C}\right)$ showed little change. If diminished bacterial respiration is characteristic of low temperature environments, or if sea ice microalgae produce bacteriostatic or bacteriocidal compounds, as suggested by Grossi et al. (1984), then slow decomposition rates could help to explain the accumulation of chl $a$ in sea ice. This view is supported by the extremely low bacterial biomass found in association with the microalgal assemblage during our study (Arrigo \& Sullivan unpubl.).

\section{Photosynthetic characteristics}

Vertical profiles of photosynthetic parameters reveal that although all platelet ice microalgae were shade adapted in 1989, the degree of shade adaptation varied with depth and time (Fig. 8). Both $P_{\mathrm{m}}^{\mathrm{b}}$ (Fig. 8A) and $\bar{a} \cdot$ (Fig. $8 \mathrm{C}$ ) declined with depth of the platelet layer, while $\phi$ (Fig. 8D) increased, consistent with expectations for cells adapting to a lower irradiance environment (Morel 1978, Atlas \& Bannister 1980, Falkowski \& Owens 1980, Perry et al. 1981, Henley \& Ramus 1989, Smith et al. 1989). Kolber et al. (1990) reported decreased $\phi$ in nutrient limited phytoplankton in the Gulf of Maine, USA, and attributed it to a reduced capacity to synthesize pigment proteins. This was not the case in our study however, because nutrient con- 
centrations remained high throughout the platelet layer, even at the congelation ice/platelet ice interface where chl a concentrations were highest (Dieckmann et al. 1992, Arrigo unpubl.). Depth-dependent changes in photosynthetic characteristics also were not the result of species specific photoacclimation responses because Nitzschia stellata dominated at all depths.

The marked variation measured in all photophysiological characteristics over such short vertical distances (between 0.06 and $0.31 \mathrm{~m}$ ) was presumably due to extreme self-shading within the highly concentrated microalgal community. Rapid attenuation of light by algal pigments was clearly observable in profiles of PAR (Fig. 5) and spectral irradiance (Fig. 6), demonstrating that the irradiance regime within the platelet layer degraded considerably with depth. Specific absorption decreased markedly (Fig. 8C) as microalgae adapted to these less favorable light regimes, due primarily to enhanced intracellular pigment concentrations (pigment packaging increases) and changes in the composition of light absorbing pigments (Morel \& Bricaud 1981, Sathyendranath et al. 1987). Pigment packaging is the result of an increase in chl a/cell or cell size and increases the absorption efficiency on a per cell basis (resulting in more similar red and blue peak heights) while at the same time decreasing absorption efficiency per unit pigment (resulting in lower $\bar{a}^{*}$ ). Microalgae living in sea ice environments in McMurdo Sound generally experience growth-limiting levels of irradiance (Arrigo et al, 1993). One adaptation appears to be increased concentrations of intracellular pigment (Robinson 1992) that can enhance their light harvesting capabilities. In particular, sea ice diatoms collected from highly shaded sea ice habitats had increased their intracellular concentrations of fucoxanthin (Robinson 1992), an accessory light harvesting pigment. This can be seen clearly by the increased light absorption in the 475 to $525 \mathrm{~nm}$ region of the spectrum (Fig. 9). Additionally, sea ice microalgae from interior or bottom ice habitats in McMurdo Sound generally are quite large, many species exceeding $100 \mu \mathrm{m}$ in length (Grossi 1985), in contrast to surface communities which are dominated by small cells $(<10 \mu \mathrm{m})$. The combination of large cell size and high intracellular pigment concentration results in a high degree of pigment packaging and thus a low $\bar{a} \cdot$ (Morel \& Bricaud 1981), particularly for algae at the base of the algal layer within the platelet ice.

Our measurements of $\phi$ for microalgae living near the top of the platelet ice layer $[0.027$ to $0.051 \mathrm{~mol} \mathrm{C}$ (Ein absorbed) ${ }^{-1}$ ] agree well with previous bulk estimates for the platelet ice community reported by SooHoo et al. (1987) which ranged from 0.018 to $0.041 \mathrm{~mol} \mathrm{C}$ (Ein absorbed) ${ }^{-1}$. Persistently low values such as these for shade adapted communities have lead some researchers to suggest that $\phi$ may be constrained by low temperature (Tilzer 1985, 1986, Palmisano et al. 1987, SooHoo et al. 1987). However, values for $\phi$ in our study increased considerably with depth within the platelet layer, in most cases approaching the theoretical maximum value of 0.125 mol C Ein absorbed $^{-1}$ These results suggest that the value of $\phi$ for sea ice microalgae is, in fact, not constrained by low temperatures, but appears to be related to the vertical position of the microalgae within the habitat. Although this spatial pattern is consistent with our understanding and with previous observations for phytoplankton which generally exhibit nearmaximal $\phi$ at the base of the euphotic zone (see review by Bannister \& Weidemann 1984), it has not been reported previously for sea ice communities. This is almost certainly because previous sampling technology precluded high resolution vertical profiling of the platelet ice community. SooHoo et al. (1987) and Palmisano et al. (1987) based their estimates of $\phi$ on bulk properties of the algal community which would be expected to mask the high $\phi$ of microalgae living near the base of the algal layer. This is easy to understand upon inspection of the vertical distributions of chl $a$ (Fig. 3) and $\phi$ (Fig. 8D) within the platelet ice. The majority of microalgal biomass was located near the congelation ice/platelet ice interface where $\phi$ was lowest; therefore any bulk estimate of $\phi$ would have been dominated by properties of the microalgae growing there.

Microalgae living near the congelation ice/platelet ice interface were well adapted to their light regime as indicated by the photoacclimation parameter, $I_{k}$ $\left(=P_{\mathrm{m}}^{b} / \alpha^{b}\right)$, which ranged from 10.9 to $13.7 \mu \mathrm{Ein} \mathrm{m}^{-2} \mathrm{~s}^{-1}$. In this region of the ice sheet (above the algal assemblage), peak noontime irradiance ranges seasonally from 5 to $100 \mu$ Ein $\mathrm{m}^{-2} \mathrm{~s}^{-1}$, depending on atmospheric conditions and the time of day when measurements were made (Palmisano et al. 1987, Arrigo et al. 1991). In contrast, on November 21, noontime irradiance was reduced to $<0.3 \mu \mathrm{Ein} \mathrm{m}^{-2} \mathrm{~s}^{-1}$ at a depth of $0.31 \mathrm{~m}$ within the platelet layer. Microalgae living at that depth exhibited an $I_{k}$ which remained an order of magnitude higher than the daily maximum light level, ranging from 2.1 to $4.8 \mu$ Ein $\mathrm{m}^{-2} \mathrm{~s}^{-1}$. The quantum yield of photosynthesis was nearly maximal at this depth within the ice, so the inability of the algae to reduce $I_{k}$ to reflect ambient irradiance conditions must be the result of either $P_{\mathrm{m}}^{\mathrm{b}}$ or $\bar{a}^{*}$ being higher than optimal ( $\alpha^{b}$ represents a balance between $\phi$ and $\bar{a}^{\bullet}$ ). The retention of excess photosynthetic capacity would imply that there is a minimum threshold for carbon uptake that an algal cell must maintain in order to remain viable, this rate perhaps being genetically programmed (Cullen 1990). Alternatively, the potential for 
intermittent exposure to higher irradiances might justify retaining additional photosynthetic capacity. Higher than optimal $\bar{a}^{*}$ might reflect a biophysical or energetic constraint to pigment packaging. Microalgae increase chl a/cell at low light levels; this ultimately leads to the pigment packaging effect observed in shade-adapted algae. Because increasing the chl af cell reduces the absorption efficiency per unit chl a (thus reducing $\bar{a}^{*}$ ), there is a point at which the energy required to incorporate additional chl a into the chloroplast becomes greater than the energy return provided by the additional light absorption by that chl $a$.

In the absence of evidence of significant algal motility (the colonial diatom Nitzschia stellata is presumably incapable of the movement observed by other pennate species), sinking, or grazing activity, the vertical distribution of chl a within the platelet ice habitat most likely reflects the decrease in the rate of algal photosynthesis observed with increasing depth. Relatively high nutrient exchange within the platelet ice (Arrigo \& Sullivan unpubl.) coupled with a superior light environment (Figs. $5 \&$ 6) should result in enhanced microalgal growth rates at the congelation ice/platelet ice interface. This is reflected in the relatively high $P_{\mathrm{m}}^{\mathrm{b}}$ measured for microalgae collected from that depth (Fig. 8A). As chl a accumulated in these upper layers, self-shading would have increased and microalgae at depth would be forced to adapt their photosynthetic apparatus to lower light availability by reducing $\bar{a}$ * and $P_{\mathrm{m}}^{\mathrm{b}}$ and increasing $\phi$. As biomass continued to accumulate, algae growing near the surface of the platelet layer would be in an increasingly favorable position for growth as the solar zenith angle, and consequently, the surface irradiance and photoperiod, increased throughout the austral spring (Fig. 4).

\section{Sustainable standing crop}

Given the anticipated degree of self-shading from such high concentrations of $\mathrm{chl} a_{1}$ it is doubtful that the entire microalgal population within the platelet ice was receiving adequate light to sustain net growth. In temperate regions the maximum vertically integrated biomass which can be supported by the available irradiance, the sustainable standing crop (SSC), has been estimated to be $400 \mathrm{mg} \mathrm{chl} \mathrm{a} \mathrm{\textrm {m } ^ { - 2 }}$ for diatom dominated communities (Steeman Nielsen 1962). This estimate for SSC was based upon the vertically integrated chl a biomass of planktonic diatoms required to reduce surface irradiance to the compensation level, $I_{C}$, $11 \%$ of surface light). By comparing integrated chl a during our study with SSC, the fraction $(\gamma)$ of the standing crop residing below the compensation depth can be estimated using the equation:

$$
\gamma=1-\frac{C_{p}+C_{c}}{S S C}
$$

Assuming that $\mathrm{SSC}=400 \mathrm{mg}$ chl a $\mathrm{m}^{-2}$ (Steeman Nielsen 1962), up to $63 \%$ of the algal standing crop would have been beneath the compensation depth within the platelet layer in 1989. Furthermore, the compensation depths on October 26, November 8, November 24, and December 3 would have been 1.05 , $0.10,0.06$, and $0.07 \mathrm{~m}$ below the congelation ice/ platelet ice interface, respectively, based upon observed chl a distributions (i.e. on October 26, the standing crop depth-integrated from 0 to $1.05 \mathrm{~m}=$ SSC). Because photosynthetic parameters can be expected to respond to the light conditions of the environment only when irradiance is greater than $I_{\mathrm{c}}$ (Yentsch \& Reichert 1963, Hellebust \& Terborgh 1967, Falkowski \& Owens 1980), algae below these depths would not be expected to exhibit shade adapted characteristics. It is clear from Fig. 8, however, that platelet ice microalgae retained their ability to photoacclimate to a depth of at least $0.31 \mathrm{~m}$ throughout the season, suggesting that SSC for sea ice microalgae must be considerably larger than $400 \mathrm{mg} \mathrm{chl} \mathrm{a} \mathrm{m}^{-2}$.

We believe that the SSC calculated by Steeman Nielsen (1962) may underestimate actual SSC for sea ice ecosystems by a factor of 1.5 to 5.0 , due to photophysiological and bio-optical differences between temperate phytoplankton and sea ice microalgae. The value of $\bar{a}$. for Antarctic phytoplankton has been found to be considerably lower than that of their temperate and Arctic counterparts (Mitchell 1991) due to pigment packaging effects (sensu Morel \& Bricaud 1981). Our results reveal that pigment-specific absorption by Antarctic sea ice microalgae is even less efficient (i.e. $\bar{a}$ * was lower) and therefore may result in an enhancement of the SSC (in terms of chl a) within sea ice. According to Eq. (7), light attenuation in sea ice is determined by $K_{\mathrm{di}}+K_{\mathrm{dp}}$ (Arrigo et al. 1991). Because $K_{\text {dp }}\left(\mathrm{m}^{-1}\right)$ is approximated by the product $C \bar{a}^{*}$ (only an approximation because scattering was ignored), the SSC of chl a given the available irradiance can be estimated using a reformulation of the Beer-Lambert Law

$$
C=-\frac{1}{\bar{a}} \cdot\left(\frac{1}{z}\right) \ln \left(\frac{I_{c}}{I_{0}}+K_{\mathrm{di}}\right)
$$

where $C\left(\mathrm{mg} \mathrm{m} \mathrm{m}^{-3}\right)$ is the mean chl a concentration over vertical distance $z(m)$ within the ice sheet, and $I_{0}(\mu$ Ein $\mathrm{m}^{-2} \mathrm{~s}^{-1}$ ) is incident PAR at the top of the platelet layer. Although, in theory, the heterogeneous distribution of chl $a$ in the platelet ice violates the Beer-Lambert Law, it has been noted that this equation can describe light transmission under these conditions with a maximum error of 5 to $10 \%$ (Gordon 1989). In any case we only wish to illustrate a qualitative trend. According to 
Eq. (9), reducing $\bar{a}^{*}$ will allow additional chl a to accumulate before $I_{0}$ is reduced to $I_{c}$. This effect is further enhanced by the low values for $I_{c}$ often exhibited by sea ice microalgae (Bunt 1964, Palmisano \& Sullivan 1983, Palmisano et al. 1987). For example, if we assume for platelet ice that $K_{\mathrm{dl}}=0.43 \mathrm{~m}^{-1}, z=0.125 \mathrm{~m}$, $I_{o}=100 \mu \operatorname{Ein~} \mathrm{m}^{-2} \mathrm{~s}^{-1}, I_{c}=5.0 \mu \operatorname{Ein~} \mathrm{m}^{-2} \mathrm{~s}^{-1}$, and $\bar{a}^{\cdot}=$ $0.02 \mathrm{~m}^{2}(\mathrm{mg} \mathrm{chl} \mathrm{a})^{-1}$ (these values for $I_{\mathrm{c}}$ and $\bar{a}^{*}$ are typical for temperate phytoplankton) then $C=1178 \mathrm{mg}$ chl $a \mathrm{~m}^{-3}$. Decreasing $\bar{a} \cdot$ to $0.006 \mathrm{~m}^{2}(\mathrm{mg} \mathrm{chl} \mathrm{a})^{-1}$ (a typical value in our study) results in a $>3$-fold increase in $C$ to $3928 \mathrm{mg} \mathrm{chl} \mathrm{a} \mathrm{m}^{-3}$, while reducing $I_{c}$ to $1.0 \mu \mathrm{Ein}$ $\mathrm{m}^{-2} \mathrm{~s}^{-1}$, a conservative value (Bunt 1964, Palmisano \& Sullivan 1983, Palmisano et al. 1987), results in an additional 1.4 -fold increase in $C$ to $6068 \mathrm{mg} \mathrm{chl} \mathrm{a} \mathrm{m}^{-3}$. Together, the reduction of $I_{c}$ and $\bar{a} \cdot$ by sea ice microalgae during photoacclimation can increase SSC by a factor of 4 to 5 .

\section{Bulk vs discrete samples}

Early determinations of photosynthetic characteristics for platelet ice microalgae relied on bulk sampling techniques which may have been misleading. This was clearly true in the case of $\phi$ for sea ice microalgae which was previously thought to be uniformly low and controlled by temperature rather than light (see discussion above). It is equally obvious when bulk population estimates of $P_{\mathrm{m}}^{\mathrm{b}}$ (Fig. 2B) are compared to values obtained from discrete depth profiles (Fig. 8A). The proportion of cells at depth with diminished photosynthetic activity increased during our study and their presence is likely to have had a substantial influence on estimates of chl a-normalized photosynthetic rates which reflect the mean for the habitat. Between midOctober and mid-November, bulk population estimates of $P_{\mathrm{m}}^{\mathrm{b}}$ declined significantly, despite the fact that no such temporal decline in $P_{\mathrm{m}}^{\mathrm{b}}$ was observed in profiles collected from the upper platelet ice (Fig. 8A) where the bulk of the biomass was located (Fig. 3). In fact, $P_{\mathrm{m}}^{\mathrm{b}}$ in the upper layer of the platelet ice increased slightly (although not significantly) through time, perhaps the result of increased surface irradiance (Fig. 4). The temporal decrease in bulk estimates of $P_{\mathrm{m}}^{\mathrm{b}}$ (Fig $2 \mathrm{~b}$ ) coincides with the depth-dependent decline in $P_{\mathrm{m}}^{\mathrm{b}}$ seen in vertical profiles (Fig. 8A). Including these depressed photosynthetic rates within the platelet ice interior in bulk averages would reduce the estimate of $P_{\mathrm{m}}^{\mathrm{b}}$. After December 3, the platelet ice layer ablated rapidly and the algal biomass from the lower portion sloughed off. Consequently, the community consisted exclusively of algae from the upper layers of the platelet ice, resulting in enhanced values for $P_{\mathrm{m}}^{\mathrm{b}}$. In the past, the seasonal decline in $P_{\mathrm{m}}^{\mathrm{b}}$ observed for algae in the platelet ice layer was thought to be due to nutrient limitation or algal senescence (Palmisano et al. 1985b). However due to the lack of clear evidence of either algal senescence or nutrient limitation during our study, it seems reasonable that seasonal changes in bulk estimates of $P_{m}^{b}$ are the result of a high and increasing proportion of photosynthetic cells with low activity from deeper within the platelet layer.

Acknowledgements. The authors thank S. Kottmeier for collecting irradiance data in 1984. Special thanks to M. Gosselin, G. Dieckmann, J. Welborn, and K. Blish for assistance in the field. We are also grateful to D. Kiefer for the use of his spectrophotometer and to R. Reynolds and D. Stramski for assistance in determining particulate absorption spectra. This work was supported by NSF grants DPP-817237 and DPP8717692 from the Division of Polar Programs to C. W. Sullivan and by a U.S. Department of Energy Global Change Distinguished Postdoctoral Fellowship to K. R. Arrigo and administered by Oak Ridge Institute for Science and Education.

\section{LITERATURE CITED}

Arrigo, K. R., Kremer, J. N., Sullivan, C. W. (1993). A simulated Antarctic fast-ice ecosystem. J, geophys. Res. 98: 6929-6946

Arrigo, K. R., Sullivan, C. W., Kremer, J. N. (1991). A biooptical model of Antarctic sea ice. J. geophys. Res. 96: 10581-10592

Arrigo, K. R., Sullivan, C. W. (1992). The influence of salinity and temperature covariation on the photophysiological characteristics of Antarctic sea ice microalgae. J. Phycol. 28: $746-756$

Atlas, D., Bannister, T. T (1980). Dependence of mean spectral extinction coefficient of phytoplankton on depth, water color and species. Limnol. Oceanogr. 25: $157-159$

Bannister, T. T (1974). Production equations in terms of chlorophyll concentration, quantum efficiency, and upper limit to production. Limnol. Oceanogr. 19: 1-12

Bannister, T. T., Wiedeman, A. D. (1984). The maximum quantum efficiency of phytoplankton photosynthesis in situ. J. Plankton Res. 6: 275-94

Bricaud, A., Stramski, D. (1990). Spectral absorption coefficients of living phytoplankton and non-algal biogenous matter: a comparison between the Peru upwelling area and Sargasso Sea. Limnol. Oceanogr. 35: 562-582

Bunt, J. S. (1964). Primary productivity under sea ice in Antarctic waters. 1. Concentrations and photosynthetic activities of microalgae in the waters of McMurdo Sound, Antarctica. Antarct. Res. Ser. 1; 13-26

Bunt, J. S., Lee, C. C. (1970). Seasonal primary production in Antarctic sea ice at McMurdo Sound in 1967. J. mar. Res. 28: $304-320$

Bunt, J. S., Wood, E. J. F. (1963). Microbiology of Antarctic sea ice. Nature 199: 1254-1255

Cullen, J. J. (1990). On models of growth and photosynthesis in phytoplankton. Deep Sea Res. 37: 667-683

Dieckmann, G. S., Sullivan, C. W., Garrison, D. L. (1990). Seasonal standing crop of ice algae in pack ice of the Weddell Sea, Antarctica. Eos (Trans. Am. geophys. Un.) 71: 79

Dieckmann, G. S., Arrigo, K. R., Sullivan, C. W. (1992). A high resolution sampler for nutrient and chlorophyl a profiles of the sea ice platelet layer and underlying water column 
below fast ice in polar oceans: preliminary results. Mar. Ecol. Prog. Ser. 80: 291-300

Duysens, L. M. (1956). The flattening of the absorption spectra of suspensions as compared to that of solutions. Biochem. Biophys. Acta 19: 1-12

Falkowski, P. J., Owens, T. G. (1980). Light-shade adaptation: two strategies in marine phytoplankton. Plant Physiol. 66 $592-595$

Gordon, H. R. (1989). Can the Beer-Lambert law be applied to the diffuse attenuation coefficient of ocean water? Limnol. Oceanogr. 34: 1389-1409

Grenfell, T. C., Maykut, G. A. (1977). The optical properties of ice and snow in the Arctic basin. J. Glaciol. 18: 445-463

Grossi, S. M. (1985). Response of a sea ice microalgal community to a gradient in under-ice irradiance. Ph.D. thesis, University of Southern California, Los Angeles

Grossi, S. M., Kottmeier, S. T., Moe, R. L., Taylor, G. T., Sullivan, C. W (1987). Sea ice microbial communities. VI. Growth and production in bottom ice under graded snow cover. Mar. Ecol. Prog. Ser. 35: 153-164

Grossi, S. M., Kottmeier, S. T., Sullivan, C. W. (1984). Sea ice microbial communities. III. Seasonal abundance of microalgae and associated bacteria, McMurdo Sound, Antarctica. Microb. Ecol. 10: 231-242

Harrison, W. G., Platt, T. (1986). Photosynthesis-irradiance relationships in polar and temperate phytoplankton populations. Polar Biol. 5: 153-164

Henley, W. J., Ramus, J. (1989). Optimization of pigment content and the limit of photoacclimation for Ulva rotundata (Chlorophyta). Mar. Biol. 103: 261-266.

Hellebust, J. A., Terborgh, T. (1967). Effects of environmental conditions on the rate of photosynthesis and some photosynthetic enzymes in Dunaliella tertiolecta Butcher. Limnol. Oceanogr. 12: 559-567

Hoshiai, T. (1981). Proliferation of ice algae in the Syowa Station area, Antarctica. Mem. Nat. Inst. Polar Res. Ser. E 34: $1-12$

Kolber, Z., Wyman, K. D., Falkowski, P. G. (1990). Natural variability in photosynthetic energy conversion efficiency: a field study in the Gulf of Maine. Limnol. Oceanogr. 35: $72-79$

Lewis, M. R., Smith, J. C. (1983). A small volume, short incubation time method for measurement of photosynthesis as a function of incident irradiance. Mar. Ecol. Prog. Ser. 13: $99-102$

Lizotte, M. P., Sullivan, C. W. (1992), Biochemical composition and photosynthate distribution in sea ice microalgae of McMurdo Sound, Antarctica: evidence for nutrient stress during the spring bloom. Antarctic Sci. 4: 23-30

Maykut, G. A., Grenfell, T. C. (1975). The spectral distribution of light beneath first year sea ice in the Arctic Ocean. Limnol. Oceanogr. 20: 554-563

Meguro, H., Ito, K., Fukushima, H. (1967). Ice flora (bottom type): a mechanism of primary production in polar seas and the growth of diatoms in sea ice. Arctic 20: $114-133$

Mitchell, B. G. (1991). Predictive bio-optical relationships for polar oceans and marginal ice zones. J. mar. Sys. 3: 91-105

Mitchell, B. G., Kiefer, D. A. (1988). Chlorophyll a specific absorption and fluorescence excitation spectra for lightlimited phytoplankton. Deep Sea Res. 35: 639-663

Morel, A. (1978). Available, usable, and stored radiant energy in relation to marine photosynthesis. Deep Sea Res. 25: $673-688$

Morel, A., Bricaud, A. (1981). Theoretical results concerning light absorption in a discrete medium, and application to specific absorption of phytoplankton. Deep Sea Res. 28 : $1375-1393$

Palmisano, A. C., Kottmeier, S. T., Moe, R. L., Sullivan, C. W (1985a). Sea ice microbial communities. IV. The effect of light perturbation on microalgae at the ice-seawater interface in McMurdo Sound, Antarctica. Mar. Ecol. Prog. Ser. 21: $37-45$

Palmisano, A. C., Lizotte, M. P., Smith, G. A., Nichols, P. D., White, D. C., Sullivan, C. W. (1988). Changes in photosynthetic carbon assimilation in Antarctic sea-ice diatoms during spring bloom: variation in synthesis of lipid classes. J. exp. mar. Biol. Ecol. 116: 1-13

Palmisano, A. C., SooHoo, J. B., Moe, R. L., Sullivan, C. W. (1987). Sea ice microbial communities. VII. Changes in under-ice spectral irradiance during the development of Antarctic sea ice microalgal communities. Mar. Ecol. Prog. Ser. 35: 165-173

Palmisano, A. C., SooHoo, J. B., SooHoo, S. L., Kottmeier, S. T., Craft, L. L., Sullivan, C. W. (1986). Photoadaptation in Phaeocystis pouchetii advected beneath annual sea ice in McMurdo Sound, Antarctica. J. Plankton Res. 8: $891-906$

Palmisano A. C., SooHoo, J. B., Sullivan, C. W. (1985b). Photosynthesis-irradiance relationships in sea ice microalgae from McMurdo Sound, Antarctica. J. Phycol. 21: 341-346

Palmisano, A. C., Sullivan, C. W. (1983). Sea ice microbial communities (SIMCO). I. Distribution, abundance, and primary production of ice microalgae in McMurdo Sound, Antarctica in 1980. Polar Biol. 2: 171-177

Palmisano, A. C., Sullivan, C. W. (1985). Physiological response of micro-algae in the ice-platelet layer to lowlight conditions. In: Siegfried, W. R., Condy, P. R., Laws, R. M. (eds.) Antarctic nutrient cycles and food webs. Springer-Verlag, Berlin, p. 84-88

Parsons, T. R., Miata, Y., Lalli, C. M. (1984). A manual of chemical and biological methods for seawater analysis. Pergamon Press, New York

Perry, M., Talbot, M., Alberte, R. (1981). Photoadaptation in marine phytoplankton: response of the photosynthetic unit. Mar. Biol. 62: 91-101

Platt, T., Gallegos, C. L., Harrison, W. G. (1980). Photoinhibition of photosynthesis in natural assemblages of marine phytoplankton. J. mar. Res. 38: 686-701

Priscu, J. C., Palmisano, A. C., Priscu, L. R., Sullivan, C. W. (1989). Temperature dependence of inorganic nitrogen uptake and assimilation in Antarctic sea-ice microalgae. Polar Biol. 9: 443-446

Robinson. D. H. (1992). Photosynthesis in sea ice microalgae: response to low temperatures and extremes of irradiance. Ph.D. thesis, University of Southern California, Los Angeles

Sathyendranath, S., Lazarra, L., Prieur, L. (1987). Variations in the spectral values of specific absorption of phytoplankton. Limnol. Oceanogr. 32: 403-415

Smith, R. C., Prezelin, B. B., Bidigare, R. R., Baker, K. S. (1989). Bio-optical modeling of photosynthetic production in coastal waters. Limnol. Oceanogr. 34: 1524-1544

SooHoo, J. B., Palmisano, A. C., Kottmeier, S. T., Lizotte, M. P., SooHoo, S. L., Sullivan, C. W. (1987). Spectral light absorption and quantum yield of photosynthesis in sea ice microalgae and a bloom of Phaeocystis pouchetii from McMurdo Sound, Antarctica. Mar. Ecol, Prog. Ser. 39: $175-189$

Steeman Nielsen, E. (1962). On the maximum quantity of phytoplankton chlorophyll per surface unit of a lake or the sea. Int. Rev. ges. Hydrobiol. 47: 333-338 
Tilzer, M. M., Bodungen, B. von, Smetacek, V. (1985). Light dependence of phytoplankton photosynthesis in the Antarctic Ocean: implications for regulating production. In: Siegfried, W. R., Condy, P. R, Laws, R. M. (eds.) Antarctic nutrient cycles and food webs. Proceedings of the 4th SCAR Symposium on Antarctic biology. SpringerVerlag, Berlin, p. 60-69

Tilzer, M. M., Elbrachter, M., Gieskes, W. W., Beese, B. (1986). Light-temperature interactions in the control of photosynthesis in Antarctic phytoplankton. Polar Biol. 5 105-111

Vincent, W. F., Howard-Williams, C. (1989). Microbial communities in southern Victoria Land streams (Antarctica). II

This article was submitted to the editor
The effects of low temperature. Hydrobiologia 172: 39-49 Welch, H. E., Bergmann, M. A. (1989). Seasonal development of ice algae and its prediction from environmental factors near Resolute, N.W.T., Canada. Can. J Fish. Aquat. Sci. 46: 1793-1804

Yentsch, C. S., Reichert, C. A. (1963). The effects of prolonged darkness on photosynthesis, respiration, and chlorophyl in the marine flagellate, Dunaliella euchlora. Limnol. Oceanogr. 8: $338-342$

Zimmerman, R. C., SooHoo, J. B., Kremer, J. N., D'Argenio D. Z. (1987). Evaluation of variance approximation techniques for non-linear photo-irradiance models. Mar. Biol. 95: $209-15$

Manuscript first received: Novmber 2, 1992

Revised version accepted: May 18, 1993 